\section{Biodegradation of Agro-industrial Waste}

\author{
D. Kučić, ${ }^{* *}$ N. Kopčić, and F. Briški \\ University of Zagreb, Faculty of Chemical \\ Engineering and Technology, \\ Marulićev trg 19, \\ HR-10000, Zagreb
}

\author{
This work is licensed under a \\ Creative Commons Atribution 4.0 \\ International License \\ doi: 10.15255/CABEQ.2017.1116 \\ Original scientific paper \\ Received: March 13, 2017 \\ Accepted: October 31, 2017
}

The production of agro-industrial waste is growing worldwide and these wastes cannot be disposed on the ground without treatment. The objective of this work was to conduct composting process and anaerobic digestion of a mixture of agro-industrial waste $(\mathrm{W})$, grape $(\mathrm{GW})$, olive $(\mathrm{OW})$ and tobacco $(\mathrm{TW})$ waste. The composting process and anaerobic digestion of the mixture of GW, OW and TW in the ratio GW:OW:TW = $1: 1: 1.98$ (dry matter) were carried out in column reactors with effective volume of 10 $\mathrm{dm}^{3}$ and $124 \mathrm{~cm}^{3}$, respectively, during 21 days. The composting experiment was carried out under forced aeration, while anaerobic digestion was conducted without aeration at temperature of $37^{\circ} \mathrm{C}$ in anaerobic digester. Three different anaerobic experiments were conducted, without inoculum (E1) and with different ratio of inoculum and waste (E2, E3). During 21 days of composting of agro-industrial waste, the obtained conversion was $50 \%$. The volume of biogas produced during 21 days in experiments E1, E2 and E3 was $256 \mathrm{~cm}^{3}, 280 \mathrm{~cm}^{3}$ and $162 \mathrm{~cm}^{3}$, respectively.

Key words:

agro-industrial waste, composting process, anaerobic co-digestion

\section{Introduction}

In Croatia, a large amount of agro-industrial wastes, like grape, olive and tobacco waste, are generated during production of wine, olive oil, and cigarettes, respectively. These wastes are characterized by high values of chemical oxygen demand (COD), biochemical oxygen demand (BOD), phenols, suspended solids, low $\mathrm{pH}$ value, high electrical conductivity, and cannot be disposed on the landfill. ${ }^{1,2}$ Agro-industrial wastes contain a considerable amount of organic matter, which can be decomposed by composting process and anaerobic co-digestion.

Composting is the aerobic biological decomposition and stabilisation of organic substrates to an end-product suitable for soil amendment or organic fertiliser. ${ }^{3}$ Composting the toxic tobacco and olive wastes, or acidic grape waste would minimise waste, and the compost could be useful for agricultural purposes. Composting of one substrate in many cases is not efficient because some wastes have low $\mathrm{C} / \mathrm{N}$ ratio (tobacco waste) and the concentration of evolved ammonia is higher, some sub-

\footnotetext{
"Presented at the " $4^{\text {th }}$ International Symposium on Environmental Management - Towards Circular Economy (SEM2016), December 7 - 9, Zagreb, Croatia"

${ }^{* *}$ Corresponding author: dkucic@fkit.hr
}

strates have low $\mathrm{pH}$ value or too high $\mathrm{C} / \mathrm{N}$ ratio (olive and grape waste). ${ }^{2}$ Furthermore, olive waste contains considerable amounts of phenols and large molecules like lignin and cellulose. Therefore, the best solution is to compost two or more substrates. The disadvantages of the composting process in an open composting pile are high odour emissions and space requirement, which is not a problem in a closed reactor.

Anaerobic digestion is a biological process that converts complex substrates into biogas and digestate by microbial action in the absence of oxygen through four main steps, namely hydrolysis, acidogenesis, acetogenesis, and methanogenesis. Anaerobic co-digestion of agro-industrial waste is of significant interest in order to facilitate a sustainable development of energy supply. Co-digestion is defined as the anaerobic treatment of a mixture of at least two different waste types in order to improve plant profitability and overcome a number of problems such as nutrient imbalance $(\mathrm{C} / \mathrm{N}$ ratio), rapid acidification, and the presence of inhibiting compounds (phenols, nicotine) among other factors. ${ }^{4-7}$ Waste biomethanation potential (BMP) depends on the concentration of the three main organic components: proteins, lipids and carbohydrates, and a substrate characterization is required to predict methane production. ${ }^{4}$ In anaerobic process, the energy is produced and there is no emission of odour. 
The aim of this work was to biologically treat agro-industrial waste, i.e., grape waste, olive waste, and tobacco waste, by the composting process and anaerobic co-digestion in a-lab-scale column reactor, because this waste cannot be disposed on the ground before treatment. The biological treatment of these agro-industrial wastes was chosen because it is an environmental friendly process and economically viable. The composting process was chosen because it gives a valuable product - compost which the farmers can use on their land, while anaerobic digestion gives biogas. Furthermore, these three wastes were selected because they are from the same area, Istria.

\section{Materials and methods}

\section{Substrate and inoculum characterization}

In this work, three different agro-industrial wastes (W) were composted and digested, i.e., grape waste $(\mathrm{GW})$, olive waste $(\mathrm{OW})$ and tobacco waste (TW). GW was generated from wine production on Plesivica Hill in the western part of Croatia, OW was generated from the production of olive oil in Istria, Croatia, and TW was generated from tobacco production in the tobacco factory TDR d.d. Rovinj, Croatia. Grape waste and olive waste contained husks and barks, and tobacco waste contained very fine powdery residue, leaf stalks and leaf parts. Inoculum (I) which was used in experiments with anaerobic digestion, was anaerobic digestate produced during wastewater treatment of baker's yeast at Pliva d.o.o. Savski Marof. The initial characterization of GW, OW, TW and inoculum are presented in Tables 1 and 2 .

\section{Composting experiments}

The composting experiment was conducted in a closed, thermally insulated reactor $\left(V_{\mathrm{r}}=10 \mathrm{dm}^{3}\right)$ at an airflow rate of $0.6 \mathrm{dm}^{3} \mathrm{~min}^{-1} \mathrm{~kg}_{\mathrm{vs}}{ }^{-1}$ (volatile solids). The temperature was monitored by thermocouples connected to the data logger during the 21 days of composting period. The composting mixture was prepared by mixing grape waste $(\mathrm{GW})$, olive waste (OW) and tobacco waste (TW) at the mass ratio of GW:OW:TW = 1:1:1.98 (dry matter). The moisture content of the substrate was set at approximately 60 mass $\%$ by adding water, and $4.0 \mathrm{~kg}$ of the mixture was fed into the reactor from the top.

During the composting, samples were collected periodically and the most relevant physicochemical properties $(\mathrm{pH}$ value, moisture content, dry matter (DM), volatile solids content (VS)), ${ }^{8}$ Kjeldahl-N content, and microbiological characteristics were determined. ${ }^{9,10}$ All physicochemical analyses were
Table 1 -Initial characteristics of GW, OW and TW

\begin{tabular}{lcc|c}
\hline & $\begin{array}{c}\text { Grape waste } \\
(\mathrm{GW})\end{array}$ & $\begin{array}{c}\text { Olive waste } \\
\text { (OW) }\end{array}$ & $\begin{array}{c}\text { Tobacco waste } \\
\text { (TW) }\end{array}$ \\
\hline Moisture/\% & 69 & 63 & 5 \\
Dry matter/\% & 31 & 37 & 95 \\
Volatile matter/\% & 93 & 97 & 78 \\
C/N ratio/- & $39 / 1$ & $60 / 1$ & $20 / 1$ \\
pH value/- & 4.3 & 4.7 & 6.2 \\
\hline
\end{tabular}

Table 2 -Initial characterisation of inoculum

$\mathrm{pH}$ value/-

7.61

Dry matter/g dm ${ }^{-3}$

15.54

Volatile matter $/ \mathrm{g} \mathrm{dm}^{-3}$

6.09

$\mathrm{COD} / \mathrm{g} \mathrm{O}_{2} \mathrm{dm}^{-3}$

9.44

$\mathrm{C} / \mathrm{N} /-$

$2.5 / 1$

carried out in duplicate and according to the Austrian standard methods for analysis of compost, which are widely used in Europe. ${ }^{8}$ Colony-forming units (CFU) of mesophilic and thermophilic bacteria and fungi were determined on the general-purpose media (nutrient agar for bacteria and malt agar for fungi) by pour plate method. ${ }^{9}$ For the plate count, a dilution series $(0.9 \% \mathrm{NaCl})$ was made from each sample. The plates were incubated under $80 \%$ relative humidity at $28{ }^{\circ} \mathrm{C}$ for the growth of mesophilic fungi, at $37^{\circ} \mathrm{C}$ for the growth of mesophilic bacteria, and at $50{ }^{\circ} \mathrm{C}$ for the growth of thermophilic microorganisms. The results were expressed as CFU of mesophilic and thermophilic bacteria and fungi per gram dry weight of the composting mass. ${ }^{10} \mathrm{Car}-$ bon dioxide $\left(\mathrm{CO}_{2}\right)$ and ammonia $\left(\mathrm{NH}_{3}\right)$ were absorbed in $1 \mathrm{~mol} \mathrm{dm}^{-3}$ sodium hydroxide $(\mathrm{NaOH})$ and $4 \% \mathrm{H}_{3} \mathrm{BO}_{3}$, respectively. $\mathrm{CO}_{2}$ was analysed daily by titration of the excess of $1 \mathrm{~mol} \mathrm{dm}^{-3} \mathrm{NaOH}$ with $1 \mathrm{~mol} \mathrm{dm}^{-3} \mathrm{HCl}^{11}$ Ammonia was trapped in 4 $\% \mathrm{H}_{3} \mathrm{BO}_{3}$ solution where an indicator $(1$ mass $\%$ bromocresol green and methyl red in alcohol solution) was added. The colour change in the solution indicated the presence of $\mathrm{NH}_{3}$. When the colour changed, $\mathrm{NH}_{3}$ was determined daily by titration with $0.1 \mathrm{~mol} \mathrm{dm}^{-3} \mathrm{HCl}$.

\section{Anaerobic digestion experiments}

The anaerobic digestion experiment was conducted in reactors with effective volume of 124 $\mathrm{cm}^{3}$. The volume of substrate was $80 \mathrm{~cm}^{3}$. Before the experimental set up, the reactors were bubbled with $\mathrm{CO}_{2}$ to ensure anaerobic conditions. The reactors were placed in a thermostat at temperature of 
$37^{\circ} \mathrm{C}$ for 21 days. The waste mixture (W) was prepared by mixing grape waste $(\mathrm{GW})$, olive waste (OW) and tobacco waste (TW) at the mass ratio of GW:OW:TW = 1:1:1.98 (dry matter). Three different anaerobic experiments were conducted: digestion of waste (W) without inoculum E1, and with inoculum E2 and E3. In experiments E2 and E3, waste mixture (W) was mixed with inoculum (I) in the ratio $\mathrm{I} / \mathrm{W}=0.2$ and 0.5 , respectively. The moisture content of substrate was 85 mass \%.

At the beginning and end of anaerobic digestion, the same analysis as in composting experiments $(\mathrm{pH}$ value, moisture content, dry matter (DM), volatile solids content (VS), N content) were performed. The chemical oxygen demand was determined according to standard methods. ${ }^{12}$

\section{Results and discussion}

\section{Composting process}

Table 1 shows initial characterization of substrate, GW, OW and TW, which were used as a substrate in a composting process and in anerobic digestion. It can be seen that GW and OW had high moisture content, about $60 \%$, while moisture of TW was $5 \%$. Furthermore, the content of volatile matter in $\mathrm{GW}$ and $\mathrm{OW}$ was also high, and $\mathrm{C} / \mathrm{N}$ ratio was greater than $35 / 1$. The $\mathrm{pH}$ value of $\mathrm{GW}$ and $\mathrm{OW}$ was in the acidic range, $\mathrm{pH}=4.5$. The content of volatile matter in TW was lower than in GW and $\mathrm{OW}$, and $\mathrm{C} / \mathrm{N}$ ratio was lower than $25 / 1$ but $\mathrm{pH}$ was 6.2. Values of $\mathrm{C} / \mathrm{N}$ ratio between $25 / 1$ and $35 / 1$ are considered to be optimal. ${ }^{2}$ If the $\mathrm{C} / \mathrm{N}$ ratio exceeds $35 / 1$, the composting process is retarded, while a ratio of less than $20 / 1$ results in a loss of nitrogen which occurs mainly as $\mathrm{NH}_{3}$ emissions. ${ }^{2}$ From the results, it can be seen that these materials cannot be composted or digested alone because of either high or low $\mathrm{C} / \mathrm{N}$ ratio and moisture content, and low $\mathrm{pH}$ value. These three substrates were chosen because they are located in the same area of Croatia.

Table 2 presents the main characterizations of inoculum used in experiment of anaerobic digestion. It can be seen that inoculum had low $\mathrm{C} / \mathrm{N}$ ratio, very high $\mathrm{COD}\left(\approx 9 \mathrm{~g} \mathrm{dm}^{-3}\right)$, and $\mathrm{pH}$ value in neutral range.

The main characteristics of the mixture of GW, OW and TW during composting process are shown in Table 3. At the beginning of the process, $\mathrm{C} / \mathrm{N}$ ratio was $35 / 1$ and at the end $25 / 1$. It can be seen that $\mathrm{C} / \mathrm{N}$ ratio and volatile matter decreased during 21 days as a result of degradation of organic matter, Fig. 1. The $\mathrm{pH}$ value of the substrate at the beginning of the composting process dropped because of production of organic acids, ${ }^{13}$ and at day 7 started to increase until the end of process due to the decom-
Table 3 -Physicochemical characterisation of the mixture of waste $(W)$ at the beginning and end of the composting process

\begin{tabular}{lcc}
\hline Time/days & 0 & 21 \\
Moisture/\% & & 60 \\
Volatile matter/\% & 85 & 78 \\
$\mathrm{C} / \mathrm{N}$ ratio/- & 35 & 25 \\
$\mathrm{pH}$ value/- & 6.23 & 9.24 \\
\hline
\end{tabular}

position of organic nitrogen that liberates ammonium, ${ }^{2,3}$ Fig. 1.

During composting, organic matter is decomposed at varying speeds at several temperature stages, in which specific microorganisms play a dominant role. Temperature is directly correlated to the biochemical activity, i.e., the heat of the reaction involved in the cellular metabolism causes a temperature increase in the composting mass. ${ }^{2,3}$ At the beginning of composting, the temperature of the composting mass was $24^{\circ} \mathrm{C}$, and at day 8 increased to $50^{\circ} \mathrm{C}$ at which it remained until day 13 when it started to decrease until the end of the process (Fig. 2).

The microbial species involved in degradation of the substrate and their number changed with the temperature changes in reactor. At the beginning of composting, the number of mesophilic bacteria was $5.38 \cdot 10^{9} \mathrm{CFU} \mathrm{g}^{-1}$, and at day 11 it exponentially increased to $6.61 \cdot 10^{12} \mathrm{CFU} \mathrm{g}^{-1}$ and remained at this level up to the end of the process. The number of thermophilic bacteria was similar to the number of mesophilic bacteria (Fig. 2). The rise in temperature in the composting mass enabled the growth of thermophilic microorganisms and their activity. In the thermophilic stage, the metabolic heat began to decrease, because the microorganisms used a large amount of energy for biodegradation of the macro-

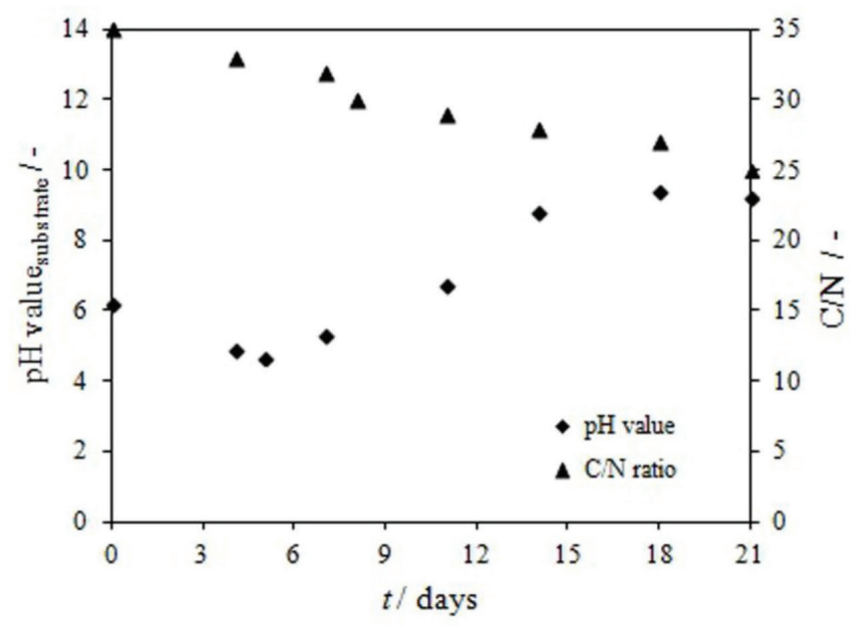

Fig. 1 - Change in $p H$ value of substrate and $C / N$ ratio during 21 days of composting 


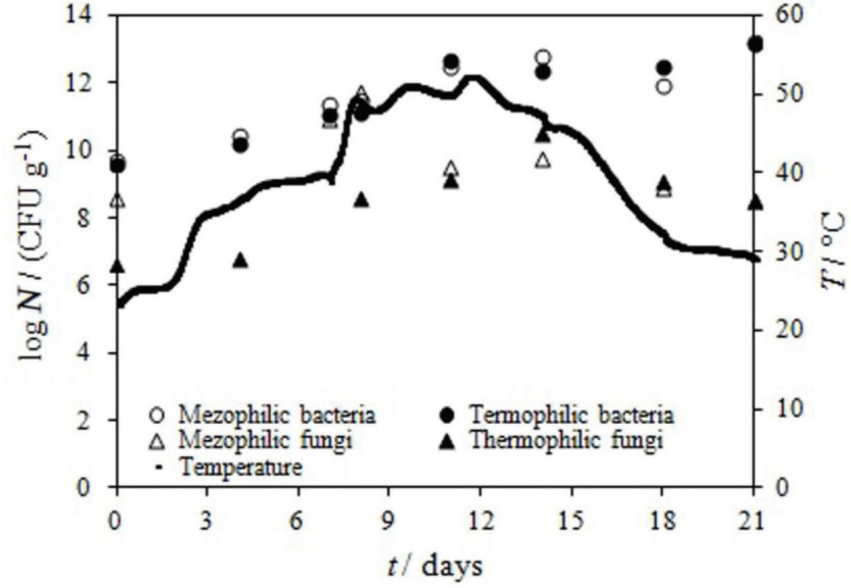

F ig. 2 - Temperature changes in composting mass and growth of microorganisms over 21 days of composting

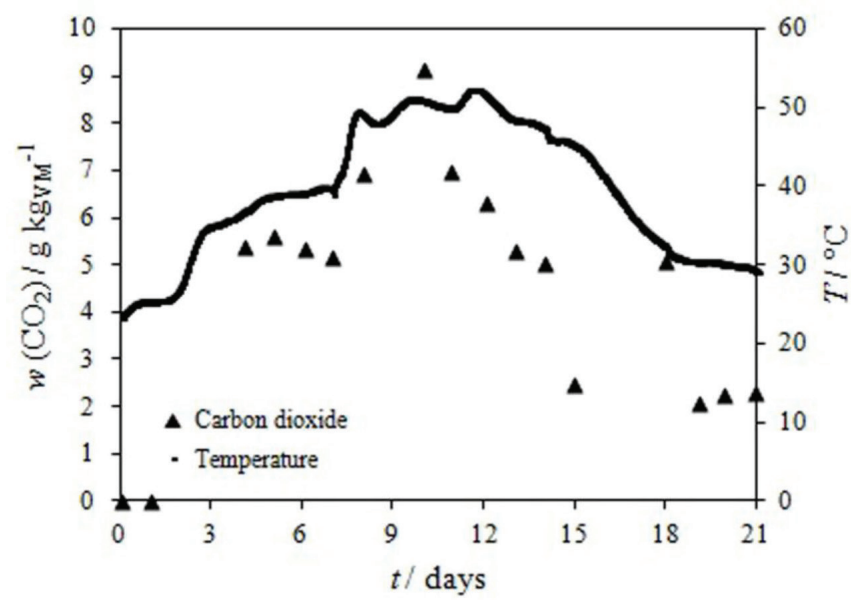

Fig. 3 -Evolution of carbon dioxide versus temperature during composting of mixture of $\mathrm{GW}, \mathrm{OW}$ and $\mathrm{TW}$

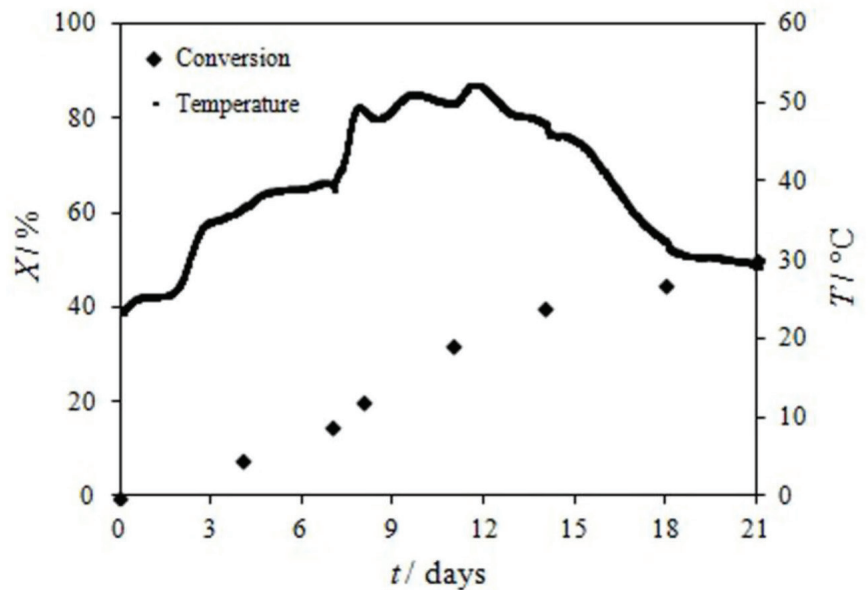

Fig. 4 - Changes in volatile solids mass in substrate during 21 days of composting process

molecules and thus the temperature began to drop. ${ }^{10}$ Besides bacteria, fungi are another kind of decomposers in the composting process. ${ }^{2,3}$ The number of mesophilic and thermophilic fungi at the beginning

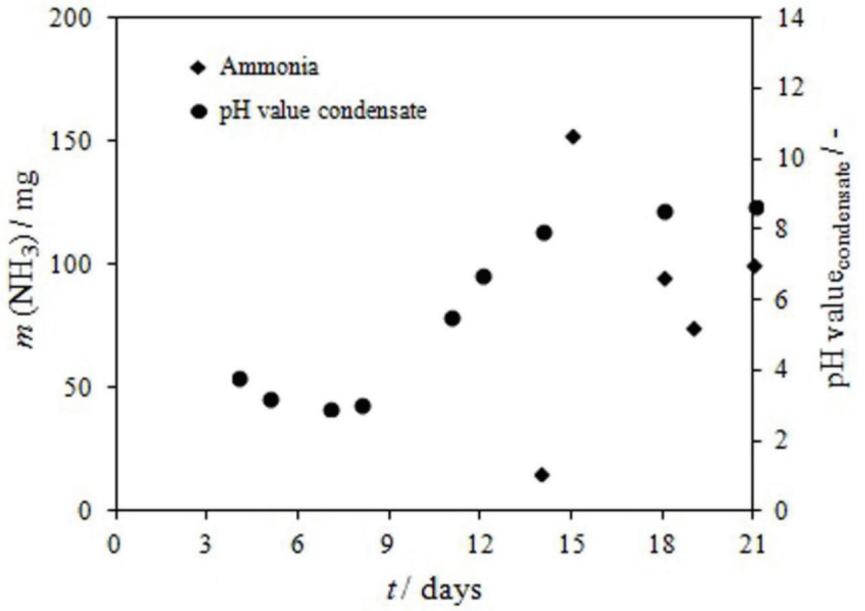

Fig. 5 - Evolution of ammonia versus $p H$ values during composting of mixture of $G W, O W$ and $T W$

of process increased from $4.28 \cdot 10^{8} \mathrm{CFU} \mathrm{g}^{-1}$ to $5.71 \cdot 10^{11} \mathrm{CFU} \mathrm{g}^{-1}$ and from $4.28 \cdot 10^{6} \mathrm{CFU} \mathrm{g}^{-1}$ to $3.02 \cdot 10^{10} \mathrm{CFU} \mathrm{g}{ }^{-1}$, respectively, and after 12 days started to decrease until the end of process.

Fig. 3 shows the emission of $\mathrm{CO}_{2}$ during the composting process. It can be seen that the dynamics of $\mathrm{CO}_{2}$ release in the compost reactor are highly influenced by the temperature regime.

The highest production of $\mathrm{CO}_{2}$ occurred in the first 12 days of the process, which was characterized by an intense biodegradation of the organic fraction of the substrate (Fig. 4) and high temperatures in the reactor and microbiological activity (Fig. 2). ${ }^{2,10}$ The most intense biodegradation was evident in the first ten days (Fig. 4). After 12 days, the concentration of $\mathrm{CO}_{2}$ decreased as the temperature decreased. The calculated conversion of volatile solids at day 12 and day 21 of the composting process was $40 \%$ and $50 \%$, respectively (Fig. 4).

Fig. 5 shows the emission of $\mathrm{NH}_{3}$ during 21 days of composting process. It can be seen that the concentration of $\mathrm{NH}_{3}$ increased at day 15 when the $\mathrm{pH}$ value of substrate and condensate was around 8 . It is well known that $\mathrm{NH}_{3}$ emission is highly dependent on the $\mathrm{pH}$ of composting materials, and that $\mathrm{NH}_{3}$ evolves as the exhaust gas when the $\mathrm{pH}$ of the composting materials exceeds approximately $8 .^{2}$

\section{Anaerobic digestion}

The main characteristics of the waste mixture (GW, OW and TW) during anaerobic digestion are shown in Table 4. The $\mathrm{pH}$ value of substrate during anaerobic digestion in experiments E1, E2 and E3 had not changed significantly, and it was within the boundaries when the biodegradation was the highest. ${ }^{14}$ From Table 4 it can be seen that, in experiment $\mathrm{E} 3$, the $\mathrm{pH}$ value was higher than in $\mathrm{E} 1$ and E2 because of the presence of inoculum, whose initial $\mathrm{pH}$ value was 7.61. The initial characteristics of 


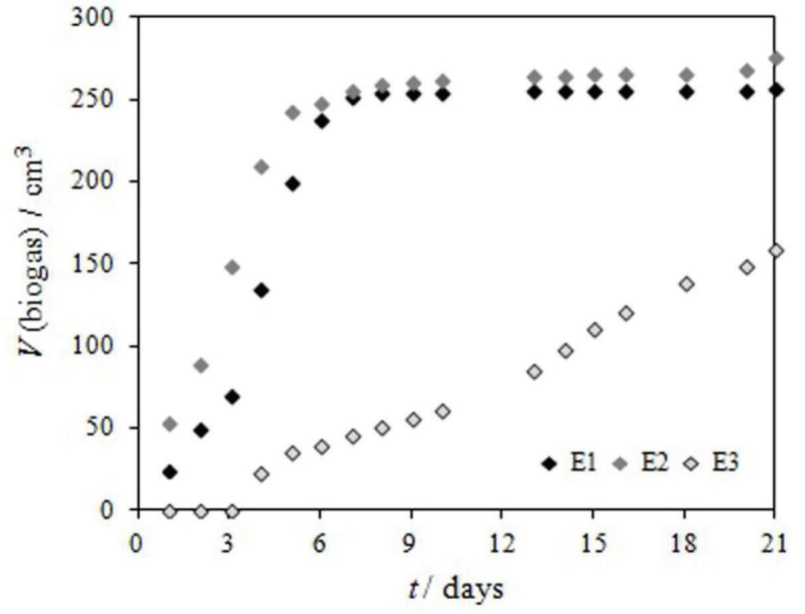

Fig. 6 - Volume of biogas evolved in anaerobic digestion of waste $(W)$ in experiments E1, E2 and E3 during 21 days

Table 4-Physicochemical characterisation of experiments E1, E2 and E3 during anaerobic digestion

\begin{tabular}{l|ccccccc}
\hline & \multicolumn{2}{|c|}{ E1 } & \multicolumn{2}{c|}{ E2 } & \multicolumn{2}{c}{ E3 } \\
\hline Time/days & 0 & 21 & 0 & 21 & 0 & 21 \\
Moisture/\% & \multicolumn{5}{c}{85} \\
$\mathrm{pH}$ value/- & 5.53 & 4.99 & 6.8 & 5.65 & 7.38 & 7.2 \\
$\mathrm{COD} / \mathrm{g} \mathrm{O}_{2} \mathrm{~g}_{\mathrm{ST}}{ }^{-1}$ & 1.45 & 1.73 & 2.15 & 1.02 & 4.48 & 3.40 \\
$\mathrm{C} / \mathrm{N} /-$ & $35 / 1$ & $25 / 1$ & $30 / 1$ & $14 / 1$ & $28 / 1$ & $17 / 1$ \\
\hline
\end{tabular}

the mixture of substrates were different than in the composting process, because for anaerobic digestion, the $\%$ moisture has to be more than $80 \%$ to ensure anaerobic conditions. The $\mathrm{pH}$ value was different because of the addition of inoculum.

During anaerobic digestion of waste (W), the COD decreased in experiments E1, E2 and E3 by $50 \%, 53 \%$ and $24 \%$, respectively, during 21 days (Table 4), which indicates the biodegradation of organic matter. The highest decrease in COD value and $\mathrm{C} / \mathrm{N}$ ratio was in the experiment E2. Fig. 6 shows that the cumulative evolved volume of biogas during 21 days in experiments E1, E2 and E3 was $256 \mathrm{~cm}^{3}, 280 \mathrm{~cm}^{3}$ and $162 \mathrm{~cm}^{3}$. It can be seen that, in experiment E2, the highest volume of biogas was evolved, which is in line with intensive decrease in COD. During the first ten days in E1 and $\mathrm{E} 2$, the production of biogas was the highest, and after ten days and until the end of the process, it changed negligibly.

\section{Conclusions}

The mixture of grape waste, olive waste, and tobacco waste was biologically treated by the composting process and anaerobic digestion during 21 days. During the composting process, the $\mathrm{pH}$ value increased from 6.23 to $9.24, \mathrm{C} / \mathrm{N}$ ratio decreased from $35 / 1$ to $25 / 1$, while the obtained conversion of substrate was $50 \%$. The cumulative evolved $\mathrm{CO}_{2}$ and $\mathrm{NH}_{3}$ during 21 days of composting was 75.41 $\mathrm{g} \mathrm{kg}_{\mathrm{VM}}{ }^{-1}$ and $438 \mathrm{mg}$.

During anaerobic digestion of waste (W) in E1, $\mathrm{E} 2$ and $\mathrm{E} 3$, the COD value decreased by $50 \%, 53 \%$ and $24 \%$, respectively. The cumulative evolved volume of biogas during 21 days in experiments E1, $\mathrm{E} 2$ and $\mathrm{E} 3$ was $256 \mathrm{~cm}^{3}, 280 \mathrm{~cm}^{3}$ and $162 \mathrm{~cm}^{3}$, respectively. Based on the results, it can be concluded that the highest biodegradation of organic matter and evolved volume of biogas was in E2, where inoculum was added in the ratio $\mathrm{I} / \mathrm{W}=0.2$.

From obtained results, it can be concluded that the examined process, i.e., composting process and anaerobic digestion, can be applied for treating agro-industrial waste.

\section{References}

1. Dermeche, S., Nadour, M., Moulti-Mati, F., Michaud, P., Olive mill waste: Biochemical characterization and valorization strategies, Process Biochem. 10 (2013) 1532. doi: https://doi.org/10.1016/j.procbio.2013.07.010

2. Kučić, D., Kopčić, N., Briški, F., Zeolite and potting soil sorption of $\mathrm{CO}_{2}$ and $\mathrm{NH}_{3}$ evolved during co-composting of grape and tobacco waste, Chem. Papers 67 (2013) 1172. doi: https://doi.org/10.2478/s11696-013-0322-z

3. Bertran, E., Sort, X., Soliva, M., Trillas, I., Composting winery waste: sludges and grape stalks, Bioresource Technol. 95 (2004) 203.

doi: https://doi.org/10.1016/j.biortech.2003.07.012

4. Álvarez, J. A., Otero, L., Lema, J. M., A methodology for optimising feed composition for anaerobic co-digestion of agro-industrial wastes, Bioresource Technol. 101 (2010) 1153 .

doi: https://doi.org/10.1016/j.biortech.2009.09.061

5. Diáz, J. P., Reyes, I. P., Lundin, M., Horváth, I. S., Co-digestion of different waste mixtures from agro-industrial activities: Kinetic evaluation and synergetic effects, Bioresource Technol. 102 (2011) 10834. doi: https://doi.org/10.1016/j.biortech.2011.09.031

6. Dareioti, M. A., Dokianakis, S. N., Stamatelatou, K., Zafiri, C., Kornaros M., Biogas production from anaerobic co-digestion of agroindustrial wastewaters under mesophilic conditions in a two-stage process, Desalination 248 (2009) 891.

doi: https://doi.org/10.1016/j.desal.2008.10.010

7. Cavinato, C., Fatone, F., Bolzonella, D., Pavan, P., Thermophilic anaerobic co-digestion of cattle manure with agro-wastes and energy crops: Comparison of pilot and full-scale experiences, Bioresource Technol. 101 (2010) 545 .

doi: https://doi.org/10.1016/j.biortech.2009.08.043

8. Austrian Standard Institute (1986). Austrian standard: Analytical methods and quality control for waste compost. ÖNORM S 2023, Vienna, Austria.

9. Prescott, L. M., Harley, J. P., Klein, D. A, Microbiology (3rd ed), Chichester, UK: WCB Publishers, 1996, pp. 498502 , 
10. Briški, F., Kopčić, N., Ćosić, I., Kučić, D., Vuković, M. Biodegradation of tobacco waste by composting: Genetic identification of nicotine-degrading bacteria and kinetic analysis of transformations in leachate, Chem. Papers 66 (2012) 1103.

11. Kolthoff, I. M., Sandel, E. B., Inorganic Quantitative Analysis, Zagreb, Croatia, Školska knjiga (1951) 347-352.

12. APHA, Standard methods for the examination of water and wastewater (16th ed), Washington, DC, American Health Public Association (1983).
13. Venglovsky, J., Sasakova, N., Vargova, M., Pacajova, Z., Placha, I., Petrovsky, M., Harichova, D., Evolution of temperature and chemical parameters during composting of the pig slurry solid fraction amended with natural zeolite, Bioresource Technol. 96 (2005) 181. doi: https://doi.org/10.1016/j.biortech.2004.05.006

14. Wang, L. K., Handbook of environmental engineering; Biological Treatment Processes, New York, 2009, 589-631. 